\title{
Bulding a Knowledge Base for Developing New Technical Solitions for the Development of Forest Roads Network
}

\author{
Shegelman Ilia Romanovich, Vasilev Aleksey Sergeevich, Galaktionov Oleg Nikolaevich, Kuznetsov \\ Alexey Vladimirovich, Sukhanov Yury Vladimirovich
}

\begin{abstract}
Currently, the transportation component in the cost of production in Russia is high and exceeds $40 \%$ in the logging industry. Among the most important trends in the development of forest transport in the country is a continuous increase in the share of timber hauling by forest hauling vehicles and an increase in the distance of timber transportation by truck-hauler trucks. At the same time, one of the main reasons hindering the development of timber industry complexes in the northern regions of Russia is the low degree of provision of forest infrastructure for transportation of business and energy wood. Therefore, considerable attention should be paid to improving the processes of forest road transport by solving the problems of developing a network of forest roads. A significant development of the network of forest roads is necessary to increase the economic accessibility of forests for clear and selective logging, thinning, and reforestation. It is also necessary to increase the economic efficiency of the operation of timber-carrying trucks during forest removal, to increase the level of development of the calculated cutting area, to increase the level of forest fire safety of forests, to prevent and extinguish forest fires. This led to the formation of a knowledge base for improving forest road transport processes by developing new technical solutions for the development of a network of forest roads. The formation of a knowledge base was made on the basis of an extended scientific, technical and patent search. Based on the knowledge base, recommendations for the development of a network of forest roads have been developed; new technologies have been proposed for involving local rocks in the processing of crushed stone for the construction of rocks, as well as the construction of temporary forest roads using logging waste.
\end{abstract}

Revised Manuscript Received on September 25, 2019

1. Shegelman Ilia Romanovich, Doctor of Technical Sciences, Professor, Cross-cutting technology and economic security, Petrozavodsk State University (PSU), 33, Lenina pr., 185910, Petrozavodsk, Republic of Karelia, Russia;

2. Vasilev Aleksey Sergeevich, Candidate of Technical Sciences, Associate Professor, Technologies and organizations of the forest complex, Petrozavodsk State University (PSU), 33, Lenina pr., 185910, Petrozavodsk, Republic of Karelia, Russia;

3. Galaktionov Oleg Nikolaevich, Doctor of Technical Sciences, Associate Professor, Technologies and organizations of the forest complex, Petrozavodsk State University (PSU), 33, Lenina pr., 185910, Petrozavodsk, Republic of Karelia, Russia;

4. Kuznetsov Alexey Vladimirovich, Doctor of Technical Sciences, Associate Professor, Technologies and organizations of the forest complex, Petrozavodsk State University (PSU), 33, Lenina pr., 185910, Petrozavodsk, Republic of Karelia, Russia;

5. Sukhanov Yury Vladimirovich, Candidate of Technical Sciences, Associate Professor, Technologies and organizations of the forest complex, Petrozavodsk State University (PSU), 33, Lenina pr., 185910, Petrozavodsk, Republic of Karelia, Russia.

Index Terms: timber road transport, knowledge base, timber hauling, forest roads, timber industry enterprises, road foundation, patent, road covering, road construction.

\section{INTRODUCTION}

Currently, the transportation component in the cost of production is high and reaches $45-48 \%$ in the logging industry, while among the most important trends in the development of forest transport in the country is the continuous increase in the share of road forest hauling and increasing the distance of forest transportation by road trains.

Improving the efficiency of transport operations and the theory of automobile forest transport was carried out by Russian scientists: Alyab'ev, V.I., Ilyin, B.A., Kuvaldin, B.I., Grehov, G.V. (1990); Afonichev, D.N., Morkovin, V.A., Goptarev, S.M. (2018); V. Kuryanov, D. N. Afonichev, O. N. Burmistrova, A. V. Skrypnikov (2002, 2007); V. K. Kuryanov, A. V. Skrypnikov, E. V. Kondrashova, V. A Morkovin (2014); B. M. Bolshakov (1998); V. A. Gorbachevsky (1984); B. A. Ilyin (1986); E. O. Salminen and G. F. Grekhov (2009); B. I. Kuvaldin and V. I. Skrypnik (1976); A. A. Kamusin, E. V. Kondrashova, D. M. Levushkin, V. A. Burmistrov (2014); Kruchinin I. N. and Sushkov S. I. (2018); V.P. Nemtsov (1982); A.P. Sokolov and V.S. Syunev, A.V. Skrynikov (2005); A.V. Skrypnikov, S.I. Sushkov, O.N. Burmistrova, D.V. Burmistrov (2017); Ngirwa, C. C., \& Ally, M. (2018); M.M. Umarov, A.V. Skrypnikov, E.V. Chernyshova, E.U. Mikova (2018); Kozlov V. G., Skrypnikov A. V., Chernyshova E. V., Mogutnov R. V., Levushkin D. M. and others.

The main purpose of forest roads as technological routes of a timber enterprise is the collection and removal of harvested forest. The dispersedness of forest reserves by area implies the existence of a set of roads, different in their capital and duration, technologically linked into a single transport network of the enterprise. During the cameral tracing of the forest road, the designer has to lay the track relying on intuition. The principal difficulty in this is the heterogeneity of the tracing terrain (relief, soil and hydrological features), the need to take into account the concentration and placement of wood reserves, as well as to observe the design standards. The solution to this problem should be sought in the development of methods for finding optimal solutions for tracing forest transport routes

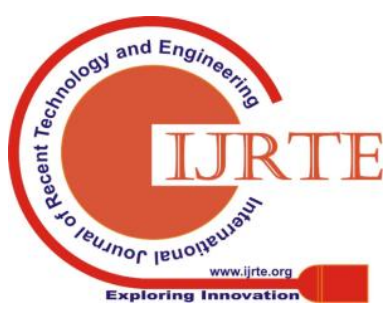


using mathematical methods and information technologies (Chernyshova et al, 2019; Singh et al., 2018).

Among foreign studies on the analyzed problem, one can single out the works: Fan, Y., Weisberg, P., Nowak, R. (2014), Hacisalihoğlu, S., Gümüş, S., Kezik, U., Karadağ, H. (2019), Heilman, Strittholt, Slosser (2002), Karjalainen in cooperation with Gerasimov, Senko (2013), Ganjali, M., \& Teimourpour, B. (2016), Holzleitner F., Kanzian, C.; Stampfer K. (2011). Rummer B., Stokes B., Lockaby G. (1997), Saibara, Nishigaki, Matsuda, Kubot. (2014), Sessions (1987), Silva F., Luciano José Minette' L. J., de Souza A. P., de Moraes A., C., Schettino S. (2016), Tinker, Resor, Beauvais, Kipfmueller, Fernandes, Baker (1998), Weintraub, Church, Murray, Guignard (2000) and others.

However, despite numerous studies of domestic and foreign experts in the field of improving the efficiency and organization of transport and switching operations, the emerging new brands and types of trucks and technologies for the construction of forest roads make the development of this area relevant today.

In addition, it is worth noting that in Russia from the 90s to the present, the volume and quality of construction of forest roads has sharply decreased. As a result, the percentage of the forest fund available under the conditions of road transport for trucks in frost-free period has decreased. The transportation network for moving raw materials from cutting areas to the end-product consumer is ramified. The nodal points of this network, in which raw materials exchanges are located, workshops and areas of timber processing enterprises are geographically dispersed. The low degree of provision of forest infrastructure for transportation of industrial and energy wood is one of the main reasons hindering the development of timber industry complexes in the northern regions of Russia. For example, in the Republic of Karelia, the average density of the road network is approximately $0.25-0.26 \mathrm{~km}$ per 100 hectares of forest area, which is four times less than the economically accessible production demand and does not correspond to the freight turnover (volumes) of forest cargoes transported (Shegelman, 2011).

Therefore, considerable attention should be paid to improving the processes of forest road transport by solving the problems of developing a network of forest roads. This led to the formation of a knowledge base to improve the processes of forest road transport for the development of new technical solutions for the development of a network of forest roads. The formation of a knowledge base was made on the basis of an extended scientific, technical and patent search. Taking into accountthe knowledge base, recommendations have been developed for the development of a network of forest roads, and new technologies have been proposed for the construction of wood waste whiskers.

\section{LITERATURE REVIEW}

Due to the need to improve the competitiveness and development of the regions of the European North, the countries for the timber industry regions of this zone, including the Komi Republic, the Republic of Karelia, the Arkhangelsk, Vologda and other areas, and in general for the timber industry regions of Russia, in recent years the problems of increasing the economic availability of forest resources and forest management intensification. In the above-mentioned regions of the European North, the country has the largest pulp-and-paper and sawmill-woodworking enterprises in the country, supplying products to the domestic and foreign markets, and poor access to forest resources may jeopardize the stability of raw wood supply from geographically dispersed forest areas and their raw material security.

We believe that it is impossible to solve these problems without an economically sound development of a network of forest roads and an increase in the economic efficiency of its operation, since the indicators characterizing this network in developed timber industry countries of Europe, especially Finland, are much higher than domestic ones. For example, in the southern zone of Karelia, the density of the network of forest roads is $3-5 \mathrm{~km} / 1000 \mathrm{ha}$, in the northern, where unique pine and spruce forests are located, this density is only 0.9-1.2 km/1000 ha. These figures are on average 4-5 times less than the standard ones and all of them are significantly lower than the average European level - about $10 \mathrm{~km} / 1000$ ha of forest.

The presence of a developed road network determines the intensity of the development of forest areas (Alyab'ev, Ilyin, Kuvaldin \& Grehov, 1990; Arutyunyan, Skrypnikov, Kozlov \& Skvortsova, 2016; Shegelman, Schukinb\& Petukhov, 2011). Higher the specific density of forest roads, higher the indicators such indicators as the development of the calculated cutting area, mechanization of labor, involvement in the industrial circulation of forest land. At the same time, the underdevelopment of the forest road network leads to a low quality of forestry work, a reduction in the level of fire safety, and a low economic accessibility of wood and other resources located in forest areas.

Significant development of the network of forest roads is necessary to improve the economic accessibility of forests for complete and selective logging, for thinning of forest, for timely and scientifically based reforestation with the economic efficiency of the operation of truck trains. This is also necessary for a significant increase in the economic efficiency of the timber truck trains during forest removal from forest areas to forest users, and, consequently, the economic efficiency of timber enterprises and the forest complex of the country as a whole, to increase the level of development of the calculated cutting area, to prevent forest fire safety and extinguishing forest fires.

The study (Gerasimov, Senko \& Karjalainen, 2013) analyzes the situation with forest roads in Russia in the context of harvesting, transportation, and forest use also as forest fire prevention. Peculiarities of the influence of timber transport vehicles on the foundations and road logging of roads are considered in (Kruchinin, 2014). Reinforced concrete pavements are 
recommended for forest roads (Moiseev, 2013).

Serious attention in road planning using geographic information systems (GIS) has been given in a number of papers (Sosa et al, 2015). For example, in the work (Silva et al, 2016) with the help of a GIS, a scheme of the road network of the study area was determined and its classification was made according to the criteria: horizontal and vertical geometry, type of road surface. At the same time, the network analysis model developed in ArcGIS allowed to establish transport routes based on the shortest distance and best performance, the latter being the most effective criterion in determining the best forest transport route. In the work (Holzleitner et al, 2011), GPS tracking wood transportation to sawmill in Austria was carried by forest truck trains along a road network, $14.2 \%$ of which was forest roads using vehicle fleet management equipment.

The work (Prokopets, Sergeev, Yushkov \& Sushkov, 2016) is devoted to the analysis of the causes of cracks in the road surfaces of forest roads. It has been established that their damage significantly reduces their service life, instead of the asphalt concrete pavements laid for 15-20 years fail after 6-8 years and the damage area reaches $60-80 \%$ of the total surface area. The main types of destruction of asphalt concrete pavements are cracks, gouges, patches, rutting, chipping, peeling, destruction of edges. The most characteristic of these are cracks. The nature of the influence of the load of timber trucks on road pavement and the roadbed of logging roads was studied in (Weinstein et al, 2012).

Serious attention in the work of Russian scientists is given to promising methods of involvement in industrial processing and the use of local mineral resources in the construction of forest roads. For example, the authors of studies (Badrudinov et al, 2016), proving the economic efficiency of using local stone material for the construction and reconstruction of forest roads, established the characteristics of changes in intergranular hollowness of compacted rubble and recommend the optimal content of a large fraction in the mixture for gravel bases of forest roads. The work (Stefan, et al 2016) explores the potential of using cubic molten slag rubble for the construction and repair of trunk forest roads. The issues of improving the transport and operational qualities of crushed stone foundations and coatings of forest roads are devoted to work (Kruchinin, 2016; Kruchinin et al, 2016). It substantiates the expediency of using easily compacting local stone material for the construction and reconstruction of forest roads. The values of the optimal content of the coarse fraction in the mixture for local stone materials, the intergranular emptiness of the gravel base and the accumulation index of the dynamic elastic modulus of the road are determined.

A series of studies is devoted to the issues of increasing the increase in the duration of the functioning of built and repaired forest roads by ensuring the safety of their surfaces of roads and foundations (Goptarev et al, 2013; Burmistrova et al, 2012; Weiss et al, 2012; Kamusin et al, 2011; Malyanova et al, 2013). In these works, we studied: the dependence of the condition of forest roads on the modifier used in the construction and repair of roads and the properties of modified bitumens, on the modified screening of limestone crushing screenings on asphalt concrete, on the size of crushed stone used, on the use of geosynthetic materials. This dependence was also studied on the use of limestone and dolomites and chemical industry wastes. Studies of the impact of rolling stock on the state of the road construction of roads, taking into account the features of forest transport, are made in (Afonichev et al, 2009).

Special attention in the research of domestic scientists is paid to the exploitation of forest roads, taking into account the seasonality of logging, and especially in winter conditions. So, for example, the possibility of preserving the anti-icing, physicomechanical and operational properties of road pavements made of crushed stone mastic asphalt concrete (CSMAC) at negative air temperatures (below - 7C ${ }^{0}$ ) and with long-term exposure to aggressive environment (water) has been proved. It is also proposed to arrange a coating of CSMAC and to vibrate its surface before mechanical removal of ice (Veyukov et al, 2014; Kotlov et al, 2013)

Studies on the use of plates and blocks of track-covering of temporary logging roads, for example, in work (Afonichev, 2005; Chernikov et al, 2014), are being offered. Composite blocks are offered for partial replacement of reinforced concrete slabs. In this paper (Stolodubtseva et al, 2014) a variant of the invention of a slab of coatings was created at the level of the invention, which is a wedge-shaped protrusion spike in the plan and section at one end of the slab and the corresponding groove on the other. The possibility of such a docking and their sides is envisaged, while the use of metal in any form at the joints is excluded, and the coating itself is almost monolithic.

A probabilistic model based in the work (Smirnov et al, 2014) relies on monitoring and statistics on the dynamics of changes in the cost of materials and services and is proposed to predict the cost of building materials, semi-finished products and energy resources during the construction of forest roads. To reduce the cost of repairing sections of forest roads by $13-14 \%$ or more, a model of inventory management has been proposed, which is recommended for planning repair activities (Kamusin et al, 2014). J. Sessions (1987), A. Weintraub, R. Church, A. Murray, M. Guignard (2000) and others have devoted serious attention to the economic and mathematical optimization of the design and creation of timber work.

Despite numerous studies on the problem under study, the issues of intensive development of the network for the northern regions of Russia remain highly relevant. The solution of this problem can be carried out on the basis of conducting extended research and forming a knowledge base and using it to develop new solutions and recommendations for the intensive development of a network of forest roads.

\section{MATERIAls AND Methods}

The purpose of the study was to create a knowledge base for

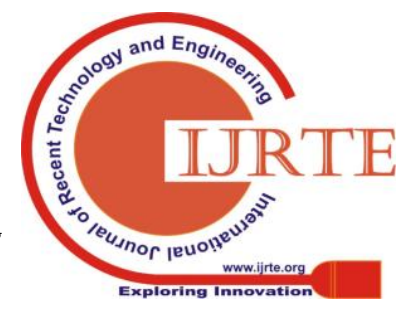


improving forest transport processes for developing new technical solutions for the development of a network of forest roads. The formation of a knowledge base was made on the basis of an extended scientific, technical and patent search.

The study is conducted in order to overcome certain difficulties in the process of learning new phenomena, to explain previously unknown facts or to reveal the incompleteness of the old ways of explaining known facts. These difficulties in the most distinct form manifest themselves in the so-called problem situations, when existing scientific knowledge is not sufficient to solve new problems of cognition.

For this purpose, a collection and subsequent analysis of the results of research and development of domestic and foreign scientists and developers, as well as inventors, has been carried out. The collection of materials was based on the fact that the active search for ways of technical re-equipment of the agro-industrial complex and the food industry, equipping them with modern machines and mechanisms, and mastering progressive processes is carried out by many scientific and experimental design organizations, universities, enterprises.

The tasks of intensive exchange of knowledge and competencies, the formation of new knowledge and competencies require large-scale access to the bases of scientific and technical information and, above all, to the bases of domestic and foreign patents. Since in Russia the Federal Institute of Industrial Property (FIPS) handles the issuance of copyright documents and the registration of intellectual property, and the most complete and reliable information is contained in the database of this organization when conducting a patent search among law enforcement documents registered in Russia, information retrieval system FIPS. When conducting a patent search for foreign patents, a database of the European Patent Office was used.

The research is based on the methodology of scientific, technical and patent search and scientific analysis of the information knowledge base. During the search, it was taken into account that its completeness and quality completely depend on the correctness of the search conditions (keywords and phrases, scope, authors and patent holders, classification indexes, etc.), and therefore a very important stage of the work is the correct formulation of the search task and careful study of its regulations.

Particular attention is paid to the analysis of patentable technological and technical solutions. When patenting, these solutions are checked for scientific novelty and successfully reflect the state and development trends of improved or newly created technology objects and technology for the development of new technical solutions for the development of a network of forest roads.

\section{RESULTS AND DISCUSSION}

The analysis showed the active development of research aimed at minimizing the cost of construction and repair of forest roads through the use of local materials and waste logging. According to the research results (Salikhov et al,
2017), the compositions and properties of the developed organic concretes were proposed (anti-icing crushed stone-mastic asphalt concrete, crushed-stone mastic asphalt concrete with limestone crushing waste and modified concrete). Cost reduction is achieved by replacing some expensive imported components with local ones: mineral powder, part of sand, and a stabilizing additive — with limestone crushing waste from local deposits. An installation for studying the adhesion forces of snow-ice deposits with surfaces of various road surfaces was considered in (Veyukov et al, 2017).

A lightweight pavement design was proposed for the construction of forest roads or transitional roads (Rashektaev et al, 03/03/2014). It consists of a roadbed, a base layer with a support layer and a coating. In this case, the support layer is made in the form of near edge of gravel berms, which are made in the form of a trapezoid. Geotextiles are laid over the subgrade and near-edge berms, which is fixed with anchors. This prevents the destruction of pavement loads of timber transport for logging highways and roads of transitional type, increases strength and extends the overhaul life of pavements.

For the construction of forest roads on weak soils: peat bogs, wetlands and frozen soils, the development can be used (Bikbau et al, 10.27.2009). According to this development, the method of road construction includes the installation of pavement on floating supports and the sealing of joints with hermetic material, characterized in that the pavement is made of prestressed reinforced concrete slabs with tongue-and-groove ends tied with steel ropes. The joints of the packages are placed on steel platforms with stop-tensioners and anchors attached to the floating supports, and after sealing the joints with a hermetic material, the supporting platforms are monolithic with concrete. Precast pavement that implements this method, made in the form of a package of plates of prestressed concrete slabs.

The technical solution (Baranov et al, February 10, 2013) includes excavation and movement of soil, formation, leveling and compaction. At the same time, excavation and movement of the soil is carried out with soil blocks, obtained by cutting vertical joints in the side reserves - two transverse and one longitudinal, one inclined seam with an angle equal to the slope of the slope, and the lower seam. The formation of the web is performed by stacking the blocks with the bottom base up and the angled side edge to the side of the road bed. The technical solution minimizes the loosening of frozen soil and reduces the energy intensity of its compaction.

The method of building a forest road (Baranov et al, 01.20.2015) is as follows. Two trenches are excavated with a length equal to the length of the road section, the track width of $1.0 \ldots 1.1$ meters and a depth of $1.0 \ldots 1.5$ meters. The distance between the trenches is 0.8 ... 1.0 meters. Short-length pieces of low-quality wood and cutting residues from the clearing of the clearing are tightly placed in trenches horizontally in height $20-30 \mathrm{~cm}$ perpendicular to the axis of the road in the form of 
transverse flooring, after which the trenches are covered with sand. Form slope slopes and transverse slope of the discharge prism. The space between trenches and slopes is filled with well-draining material (sand, gravel, crushed stone, etc.) and compacted. This creates a common basis for the trenches and the construction of a gravel road pavement, and the trenches perform the functions of the track-borne part of the technological logging road. This technical solution is the development of developments, according to which low-quality wood and logging residues left after logging operations are used as wooden elements (Baranov et al, $01.20 .2012 ; 08.20 .2012)$. It is necessary to bring a technical solution (Baranov et al, 05/23/2018), according to which wooden elements are installed vertically into the split at the bottom of trenches with subsequent simultaneous pressing of wooden elements into the bottom and the formation of internal and external lateral slopes of trenches, which are given a prismatic shape.

For the construction of forest roads, a method of compacting concrete with aggregates from local road-building materials was proposed (Lifantev et al, 10/20/2018). The method involves power compression with simultaneous vacuuming of concrete during lying. Local road-building materials that are part of concrete (water and cement) undergo sequential vacuuming: during dosing, during transportation, when loading into the mixer, while mixing until the concrete is ready for the start time of cement mortar crystallization, and also evacuating the concrete when laying it on concreted surface and vacuuming the evacuated concrete when it is compacted by mechanical action on the

A number of specialists (Shirnin et al, 08/20/2013) have proposed a method that can be used when cutting down forest roads, as well as when cutting forest areas for oil and gas pipelines and transmission lines (TL). This method includes operations: cutting trees with chainsaws in the direction from the developed part of the route, trimming, cutting the logs and laying the branches on the future road using a delimbing-bucking machine, loading and transporting the assortments of a haul truck train with a manipulator that drives, for example, backwards to the strip of laid boughs at a distance equal to the length of the pack set, and on the return path it loads the assortments located to the left and to the right of the strip before collecting the full-load pack. Then take out the sort assortments, and roll processing felled trees and depend on the location of the tree is cut by the width of strips of wood. In this case, the felling of a tree on the route of the future road is carried out in a direction parallel to its axis and the pruning of branches and bucking is performed by a processor. Due to this, the energy intensity and environmental impact on the forest environment is reduced by eliminating skidding while simultaneously arranging the forest carrying road on overmoistened soils. This road will be used for the construction and maintenance of oil and gas pipelines and transmission lines.

In the work of specialists (Rodin et al, 04/20/2015) considers the technology of construction of forest roads (whiskers - elements of forest roads on logging sites). The concreted surface.

method involves tracing, cutting down trees flush with the ground, cleaning them from a future road, strengthening forest remains of wet places. In agriculture, a system of deep soil tillage is known, involving a combination of waste dumps, tiller-free and surface treatments, as well as measures to enhance the use of subsoil layers of soil, which makes it possible to soften (recultivate) compacted soil layers. A disadvantage of the known technology of multi-depth tillage is the impossibility of its use in the forest, which has, essentially, a higher density and hardness of the track from the forest-carrying machinery, due to its saturation with forest debris, roots, and the limited area of impact on the biogenic cenosis. The elimination of this drawback is achieved by the fact that in the technology of multi-depth soil tillage by surface and bottomless methods, surface treatment is carried out by double-breaking the forest-carrying road 250-270 cm wide and 12-15 cm deep, and the bottom-free one by single-slitting (cutting the litter, humus, podzolic and partially illuvial soil layers) in the center of the road (whisker) to a depth of 50-60 $\mathrm{cm}$. The proposed method of decompression of forest roads (whiskers) allows you to change the density of the soil along the surface and slit forest road, will create conditions for removal of surface water to the lower horizons, thereby changing the conditions of humidity, temperature, air exchange, which will help to speedily overcome the negative anthropogenic impact on the biogeocenosis and create favorable conditions for the implementation of reforestation operations, will raise bonitet of created plantations.

Specialists (Tyurin, 2011) note that theory and practice show that it is recommended to use separating and reinforcing layers of geosynthetic materials to strengthen the weak soils of the road base and increase their bearing capacity. Specialists (Sushkov et al, 2018a) note that the use of geosynthetic and geoplastic materials in the construction of forest roads makes it possible to increase the durability of road structures, reduce labor and energy costs, simplify technology, improve the quality and culture of production, and reduce construction time.

Methods have been developed for constructing road logging roads on grounds with a low bearing capacity of soils (Naskovets et al, 2015). These methods allow you to evenly distribute the transmitted load from the embankment through the sealing layer on the weak base. The proposed designs of forest roads, containing layers of geosynthetic materials and wooden elements, can reduce the volume of earthworks by $20 \%$, increase the carrying capacity and replace expensive road-building materials with local soils with effective use of geosynthetic materials.

The analysis showed that in order to realize the task of full and economically beneficial use of wood resources, first of all, it is necessary to create satisfactory conditions for carrying out transport and displacement operations as the most important part of the production process of logging, during which wood moves along walkways, whiskers, branches and highways with forest machines.

On the basis of the analysis

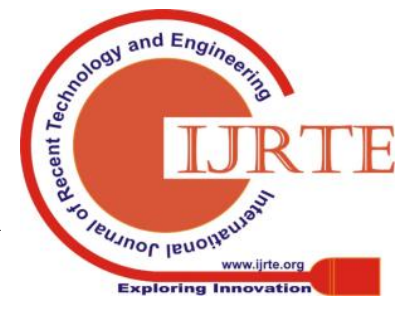


performed, the authors, with the participation of V. I. Skrypnik, proposed a method for creating a covering of whiskers in areas with a low bearing capacity of soils (Shegelman, et al, 04.20.2013). The method includes felling, skidding and pruning tree branches, covering the whiskers with wood waste. Trees felled using a feller-trelevo-processor machine trek to the whisker track, placing them with the butt to the whisker track, then the felling and skidding-processor machines pruning branches and bucking trees on assortments that are laid on the opposite side of the whisker. Twigs and tops of trees lay on the route of the whisker. Next, using forwarders produce sorting and piling of assortments. Forwarder, moving on the laid wood waste compacts them. After the end of the skidding of trees, their bucking and laying of branches and tops in the cover of a whisker on the one hand repeat all operations from the opposite side of the whisker. This provides an increase in productivity and a reduction in the cost of building temporary roads (whiskers) in areas with low bearing capacity of soils.

The authors consider it necessary to note that transport and switching operations play an important role not only for forest industry (Voronin, 2012; Sushkov, et al., 2015; Shegelman, 2013), but also for agro-industrial complexes and food production (Shegelman et al, 2018). A common feature is the presence of multi-level geographically distributed transport and production systems that function effectively with a scientifically based combination of technological operations and the acquisition of end-to-end technologies with machines and equipment.

The authors believe that one of the promising solutions to the problem of using local materials for the construction of permanent forest roads, as well as roads of transitional type, may be the solution of the problem of developing and scientifically justifying technologies for disintegrating overburden and host rocks of various genetic types to obtain building rubble. The urgency of the task is due to the fact that the current stage of development of the subsoil is characterized by the fact that the resources of many large deposits are close to exhaustion, and the prospects for discovering new deposits with significant reserves of rich ores are extremely low. In this regard, there is a need to engage in commercial operation of small deposits of ores of complex material composition. Requirements for the quality of crushed stone are constantly increasing, which is associated with an increase in the speed and intensity of road transport, as well as the development of a network of high-speed railways and the improvement of industrial and civil engineering technologies. The authors studied the issues of creating a technology for crushing rocks with obtaining high-quality cubical crushed stone while minimizing the energy consumption for its production and reducing the yield of screenings as poorly liquid products. Some technical solutions to this problem are given in the authors' works (Vasilev et al, 2016; Kameneva et al, 2016) and in a number of patents (Shegelman et al, 07/01/2015, 12/10/2017).

The analysis showed that the problem of the development of a network of forest roads is particularly relevant for the northern regions of Russia, where transport operates in the presence of geographically distributed producers and consumers of products in large areas.

This led to the formation of a knowledge base for improving forest road transport processes by developing new technical solutions for the development of a network of forest roads. The formation of a knowledge base was made on the basis of an extended scientific, technical and patent search. Based on the knowledge base, recommendations for the development of a network of forest roads have been developed; new technologies have been proposed to involve local rocks in the processing using modern production technologies for building rubble roads, as well as the construction of temporary forest roads using logging wastes.

\section{Conclusion}

The need to improve the efficiency of timber hauling processes highlights the requirements for the quality of construction and the condition of existing timber carrying roads. In this case, the roads under construction - branches and highways cannot always be used for the removal of wood all year round. A significant part of the harvested wood of the enterprise has the ability to withdraw on the roads only in the winter period, in the presence of stable subzero temperatures. Common problems in the transport of wood resources in Russia are the following (Shegelman et al, 2011):

Underdevelopment of the transport network: sections of the transport network have limitations on maximum throughput; the length of forest roads per square kilometer of forest area is low to involve the full potential of forest resources in the production process; low technical condition of a significant part of public roads; the discrepancy between the general transport scheme and current needs leading to congestion and underloading of various sections of the transport network; insufficient development of railway infrastructure.

Limitations of the haul distance by type of vehicle: the distance at which the profitability of hauling by road is maintained, according to various sources, varies from 100 to $300 \mathrm{~km}$; railway transportation is economically more feasible than road transport only with significant volumes of transportation over long distances; each loading and unloading can have a negative impact on roundwood, therefore, transport with a minimum number of loading and unloading operations should prevail; there is a need for the organization of intermediate storage of wood during transportation over long distances.

To realize the task of full and economically advantageous use of wood resources, first of all, it is necessary to create satisfactory conditions for carrying out transport and interchange operations as an essential part of the production process of logging, under which wood moves along walkways, whiskers, branches and highways with forest machines.

In the Republic of Karelia, on leased forest areas, the length of public roads that 
tenants use for harvesting and transporting timber amounts to an average of $30 \%$ of the road network. However, it should be noted that they are used more intensively, because after the bucking into assortments, further movement of wood, transportation of timber to the consumer is mainly carried out on public roads (local, republican and partially federal) from lower warehouses and reloading points adjacent to arranged roads. Currently, in the logging industry the transportation component in the cost of production in Russia is high and reaches $45-48 \%$, while among the most important trends in the development of forest transport in the country is the continuous increase in the share of road forest hauling and the increase in the distance of forest transportation by road trains. At the same time, one of the main reasons hindering the development of timber industry complexes in the northern regions of Russia is the low degree of provision of forest infrastructure for transportation of business and energy wood.

A significant development of the network of forest roads is necessary to increase the economic accessibility of forests for clear and selective logging, thinning, and reforestation. It is also necessary to increase the economic efficiency of the operation of timber-carrying trucks during forest removal, to increase the level of development of the calculated cutting area, to increase the level of forest fire safety of forests, to prevent and extinguish forest fires. This led to the formation of a knowledge base to improve the processes of forest road transport for the development of new technical solutions for

The presence of a developed road network determines the intensity of the development of forest areas. The higher the specific density of forest roads, the higher the indicators such indicators as the development of the calculated cutting area, mechanization of labor, involvement in the industrial circulation of forest land. At the same time, the underdevelopment of the forest road network leads to a low quality of forestry work, a reduction in the level of fire safety, and a low economic accessibility of wood and other resources located in forest areas.

The analysis allows us to state the extreme relevance of research by Russian and foreign scientists aimed at solving for forestry regions of the northern territories the problems of increasing the economic accessibility of forest resources and achieving effective indicators of the economics of forest use.

A significant place in solving this problem is occupied by search and applied research on the development of a network of forest roads and the economic efficiency of its operation. These studies are based on the use of modern methods of economic and mathematical modeling and solve important problems of increasing the economic efficiency of forest roads and equipment for their operation and construction, including during the winter season; ensuring the preparation of cost-effective materials for the construction and repair of road logging of roads, including local mineral resources and energy-efficient production of crushed stone with minimal loss of raw stone; optimization of costs for the design of road forest transport networks with the justification of network options to minimize the economic costs of forest transport; the development of a network of forest roads.

optimization of the construction and repair of forest roads with a decrease in resource consumption; use in the construction and repair of forest roads fundamentally new durable building materials and products, including geosynthetic; forecasting the seasonality periods in logging management, etc., affecting the economic efficiency of forest transport and the functioning of forest roads, etc.

The authors believe that one of the promising solutions to the problem of using local materials for the construction of permanent forest roads, as well as transitional roads, could be the solution of the problem of developing and scientifically justifying technologies for disintegrating overburden and enclosing rocks for building rubble. The urgency of the task is due to the fact that the current stage of development of the subsoil is characterized by the fact that the resources of many large deposits are close to exhaustion, and the prospects for discovering new deposits with significant reserves of rich ores are extremely low. There is a need to engage in commercial operation of small deposits of ores of complex material composition. When solving these issues, the studies of the authors cited in (Vasilev et al, 2016; Kameneva et al, 2016) and in a number of patents (Shegelman, et al, 07/01/2015, 12/12/2017) can be used.

The knowledge base formed in the course of the research can be used to select and synthesize new solutions aimed at improving the development of the network of forest roads and improving the efficiency of their functioning.

\section{REFERENCES}

1. Fan, Y., Weisberg, P. \& Nowak, R. (2014). Spatio-temporal analysis of remotely-sensed forest mortality associated with road de-icing salts. The Science of the Total Environment. Vol. 472. 929-938.

10. Silva, F., Luciano José Minette, L. J., de Souza, A. P., de Moraes, A., C. \& Schettino S. (2016). Classification of forest roads and determination of route using geographic information system. Revista Árvore. Vol. 40. No 2 http://dx.doi.org/10.1590/0100-67622016000200015. Retrieved from http://www.scielo.br/scielo.php?script=sci_arttext\&pid=S0100-6762201 6000200329

11. Sosa, A., Kevin, McDonnell K. \& Ger Devlin G. (2015). Analysing Performance Characteristics of Biomass Haulage in Ireland for Bioenergy Markets with GPS, GIS and Fuel Diagnostic Tools. Retrieved from https://www.mdpi.com/1996-1073/8/10/12004/htm

12. Tinker, D. B., Resor, C. A. C., Beauvais, G. P., Kipfmueller, K. F., Fernandes, Ch. I. \& Baker, W. L. (1998). Watershed analysis of forest fragmentation by clearcuts and roads in a wyoming forest. Landscape Ecology. Vol. 13. No 3. 149-165.

13. Vasilev, A. S., Shegelman, I. R., Aminov, V. N., Kameneva, E. E. \& Shchukin P. O. (2016). Philosophy of Technical Equipment Improvement as Exemplified by a Jaw Crusher. Indian Journal of Science \& $\begin{array}{llllll}\text { Technology. } & \text { Vol. } & 9 & \text { (46). } & \text { Retrieved from }\end{array}$ http://www.indjst.org/index.php/indjst/article/view/107536v

14. Weintraub, A., Church, R. L., Murray, A. T. \& Guignard, M. (2000) Forest management models and combinatorial algorithms: analysis of state of the art. Sessions, J. A. Annals of Operations Research, no 96. 271-285.

15. Alyab'ev, V.I., Ilyin, B.A., Kuvaldin, B.I. \& Grehov, G.V. (1990). Forest land transport. Moscow: Lesnaya promyshlennost'.

16. Afonichev, D.N. (2005). Improving the theory of calculation and design parameters of precast coatings for timber roads. Voronezh.

17. Afonichev, D.N. \& Zanin, A.A. (2009). Comprehensive assessment of the impact of rolling stock on the road structure in the computer-aided design system, taking into account the characteristics of forest transport Modelirovaniye sistem i protsessov, no 3-4. 23-28.

18. Afonichev, D.N., Morkovin, V.A. \& Goptarev, S.M. (2018). Optimization of the integrated process of hauling timber from logging sites. Lesotekhnicheskiy zhurnal. Vol.8.No 2(30). 132-141.

19. Arutyunyan, A. Yu., Skrypnikov, A. V., Kozlov, V. G. \& Skvortsova, T. V. (2016). Automated design of 
the forest road. Automation. Sovremennyye tekhnologii, no 6. 38-41.

2. Gerasimov, Y., Senko, S. \& Karjalainen, T. (2013). Prospects of forest road infrastructure development in northwest Russia with proven Nordic solutions. Scandinavian Journal of Forest Research. Vol. 28. No 8 . 758-774.

20. Batrudinov, A.N., Sangadzhiev, M.M., Erdniev, O.V. \& Ledzhinov, V.S (2016). Investigation of the physico-mechanical properties of local building materials to strengthen the shoulders (Lower Volga Region). Geologiya, geografiya i global'naya energiya, no 2(61). 14-29.

21. Baranov, A.N., Kisilev, A.E. \& Burshina, M.P. (23.05.18). Patent of the Russian Federation No. 2654930 "Method of construction of a technological logging road section".

22. Baranov, A.N. \& Plyaskin, A.V. (20.01.2015). Patent of the Russian Federation No. 2539473 "Road clothes "Method of construction of a technological logging road section".

23. Baranov, A.N. \& Chumakov, V.F. (10.02.2013). The patent of the Russian Federation № 2539473 "Method of construction of a road bed".

24. Baranov, A.N., Chumakov, V.F. \& Yasinskiy, R.A. Baranov, A.N. \& Chumakov, V.F. (20.08.2012). Patent of the Russian Federation No. 2539473 "Method of construction of a technological logging road section".

25. Bikbau, M.Ya., Miroshnikov, A.I. \& Levin, B.A. (27.10.2009). Patent of the Russian Federation No. 2371537 "Method of road construction on weak and frozen soils and precast coating for its implementation."

26. Bolshakov, B.M. (1998). Central Scientific Research and Design and Design Institute of Mechanization and Energy of Forest Industry (CSRDIMEFI) and scientific and technical progress in the timber industry Khimki. CSRDIMEFI.

27. Burmistrova, O. N., Plastinina, E. V. \& Voronina, M. A. (2012) Justification of design schemes and mathematical models of non-rigid pavements, reinforced with geosynthetic materials. Vestnik Povolzhskogo GTU. No. 1 (15). 45-51.

28. Weinstein, E. V., Salikhov, M. G., Weinstein, V. M., Nekhoroshkov, P. A (2012). Investigation of changes in the vertical displacements from the load of logging trucks in the design of road pavement and the road bed by the finite element method. Sovremennyye problemy nauki i obrazovaniya, no 6.

29. Weiss, K.E. \& Nikolaev, G.B. (2012). Features of the construction of forest roads in difficult engineering and geological conditions in the North of the European part of Russia. In the collection: Oriented fundamental and applied research is the basis for the modernization and innovative development of the architectural, construction and road-transport complexes of Russia. 56-66.

3. Hacisalihoğlu, S., Gümüş, S., Kezik, U. \& Karadağ, H. (2019). Impact of Forest Road Construction on Topsoil Erosion and Hydro-Physical Soi Properties in a Semi-Arid Mountainous Ecosystem in Turkey. Polish Journal of Environmental Atudits, no 28(1). 113-121.

30. Veyukov, E.V. \& Gilyova, Yu.A. (2014). Economic efficiency of the implementation of anti-icing crushed stone-mastic asphalt concrete Proceedings of the Volga State Technological University. Series: Technological. No 2. 228-230.

31. Veyukov, E.V. \& Shigapov, R.R. (2017). Installation for determining the forces of adhesion of ice with the surfaces of the roads' pavements. Modernization and scientific research in the transport complex. Vol. 1. 192-196.

32. Voronin, A.V. (2012). Experience in the formation of models, methods and algorithms for integrated planning and management of material flows in multi-level geographically distributed transport and production systems. Inzhenernyy vestnik Dona, no 2 (20). 456-459.

33. Goptarev, S.M. \& Morkovin, V.A. (2013). Justification of the volume of construction of temporary forest roads. Voronezhskiy nauchno-tekhnicheskiy Vestnik, no 4 (6). 76-83.

34. Gorbachevsky, V.A. (1984). Wood removal technology and logging efficiency. Promyshlennyy transport, no 1. 20-23.

35. Ilyin, B.A. (1986). Traction and operational calculations in the design of forest roads. Leningrad: $L T A$

36. Kamusin, A.A., Kondrashova, E.V., Levushkin, D.M. \& Burmistrov, V.A (2014). Resource support of the process of construction, repair and maintenance of forest road sections. Forestry Bulletin, no 2(101).21-27.

37. Kamusin, A.A. \& Levushkin, D.M. (2011). Investigation of the working capacity of the working layer of surface treatment of forest roads based on traditional and modified bitumen. Forestry Bulletin, no 5. 70-74.

38. Kotlov, V. G., Salikhov, M. G., Veiukov, E. V., Zheleznova, T. V. \& Weinstein, E. V. (2013). On the use of crushed stone-mastic asphal concrete to cover the streets of asphalt granulate cold milling. Vestnik Volgogradskogo gosudarstvennogo arkhitekturno-stroitel'nogo universiteta. Seriya: Stroitel'stvo i arkhitektura, no31-2 (50). 441-444.

39. Kruchinin, I. N. (2016). Justification of the use of stone materials in the construction of foundations and coatings of forest roads Lesotekhnicheskiy zhurnal. Vol. 6. No 2 (22). 84-90.

4. Heilman, Jr., Strittholt, J. \& Slosser, N. (2002). Forest fragmentation of the conterminous United States: assessing forest intactness through road density and spatial characteristics. Bioscience. Vol. 52. No 5. 411-422.

40. Kruchinin, I.N. \& Sushkov, S.I. (2016). Improving the transport and operational qualities of gravel bases and coatings of forest roads. Stroitel'nyye i dorozhnyye mashiny, no 6. 36-38.

41. Kruchinin, I. N. (2014). Assessment of the impact of timber transport machines on the foundations and the coverage of forest roads. Transport. Transportnyye sooruzheniya. Ekologiya, no 4. 40-48.

42. Kuvaldin, B.I. \& Skrypnik, V.I. (1976). Calculations on the computer modes of movement of timber-back trucks. Izvestiya vuzov: Lesnoy zhurnal, no 6. 60-65.

43. Kuryanov, V. K. \& Afonichev, D. N. (2007). Car roads. Voronezh. 284.

44. Kuryanov, V. K., Afonichev, D. N., Burmistrova, O. N. \& Skrypnikov A. V. (2002). Improving the convenience and safety of the movement of timber trucks on curves of small radius. Vestnik Tsentral'no-Chernozemnogo regional'nogo otdeleniya nauk o lese. Vol. 4. No 1. 178-187.

45. Kuryanov, V. K., Skrypnikov, A. V., Kondrashova E. V. \& Morkovin V. A (2014). The model of traffic flow on forest roads. Izvestiya vysshikh uchebnykh zavedeniy «Lesnoy zhurnal». No 2. 61-67.

46. Lifantev, V.I., Salikhov, M.G. \& Yezhova, S.V. (20.10.2018). Patent of the Russian Federation No. 2336387 "Method of compacting concrete with aggregates from local road-building materials".

47. Malyanova L. I. \& Salikhov M. G. (2013). Study of the effect of the modified additive on some properties of asphalt concrete with limestone crushing screenings for covering forest roads. Vestnik Povolzhskogo gosudarstvennogo tekhnologicheskogo universiteta. Seriya: Les. Ekologiya. Prirodopol'zovaniye, no 1 (17). 64-71.

48. Moiseev, V.I. (2013). Increase of the transport and operational level of pavements of forest roads with use of a rubber crumb. Krasnoyarsk.

49. Naskovets, M. T., Drachilovsky, A. I. \& Dini, M. N. (2015). Interaction of forest road embankments containing reinforcing layers with peat bases. Vestnik Sibirskoy gosudarstvennoy avtomobil'no-dorozhnoy akademii, no 6 (46). 71-76.

5. Holzleitner, F., Kanzian, C. \& Stampfer, K. (2011). Analyzing time and fuel consumption in road transport of round wood with an onboard manager. European Journal of Forest Research, Vol.130. No 2.293-301.

50. Nemtsov, V.P. \& Shestakov, B.A. (1982). Operation of road transport in timber company. Moscow: Lesnaya promyshlennost'.

51. Prokopets A.S., Sergeev, A.S., Yushkov, B.S. \& Sushkov, S.I. (2016) Formation of transverse cracks in asphalt concrete pavements of logging roads arranged on slopes. Al'ternativnyye istochniki energii $v$ transportno-tekhnologicheskom komplekse: problemy $i$ perspektivy ratsional'nogo ispol'zovaniya. Vol. 3. No 3 (6). 380-386

52. Raschektaev, V. A., Kruchinin, I. N. \& Chudinov, S. A. (10.12.2014). The patent of the Russian Federation No. 148339 "Road coverage".

53. Rodin, S. A. \& Degtev, V. T. (04/20/2015). Patent of the Russian Federation No. 2459899 "Method of decompression of forest roads."

54. Salikhov, M. G., Weinstein, V. M. \& Veyukov, E. V. (2017). New organic concretes and features of their production and use technologies. Vestnik Povolzhskogo gosudarstvennogo tekhnologicheskogo universiteta. Seriya: Materialy. Konstruktsii. Tekhnologii. No 2. 38-43.

55. Smirnov, M. Yu., Skrypnikov, A. V., Kondrashova, E. V., Dorokhin, S. V. \& Skvortsova, T.V. (2014). Methods, models, algorithms for managing the process of construction, repair and maintenance of forest roads in conditions of limited resources. International Journal of Applied and Fundamental Research, no 6. 126-128.

56. Storodubtseva, T.N., Chernikov, E. A., Tomilin, A. I. \& Aksomitny, A. A (2014). Calculation of slabs of temporary forest roads from polymer sand composite materials (PPKM). Aktual'nyye napravleniya nauchnykh issledovaniy XXI veka: teoriya i praktika. Vol. 2. No 2-1 (7-1). 489-493.

57. Sushkov, S. I., Burmistrova, O. N. \& Burmistrov D. V. (2017). Improving the performance of forest roads. Voronezh. 163

58. Sushkov, S.I., Burmistrova, O.N. \& Pilnik, Yu.N. (2015). Principles of solving management problems in multi-level transportation and production systems of the forest complex. Fundamental'nyye issledovaniya, no 11-2. 317-321.

59. Sushkov, S.I., Knyazev, A.V. \& Vostrikov, D.S. (2018a). On the use of geosynthetic materials in the construction of forest roads. No 1(23).15-21

6. Kameneva, E. T., Aminov, V. N., Shegelman, I. R., Vasilev, A. S. \& Shchukin, P. O. (2016). Specifics of Studying Crushability of Construction Rocks. Indian Journal of Science \& Technology. Volume 9, Issue 46. Retrieved http://www.indjst.org/index.php/indjst/article/view/107540 
60. Tyurin, V.I. (2011). Questions of the use of geosynthetic materials in road construction in the design of forest roads. Dorogi. Innovatsii $v$ stroitel'stve. No 7. 22-27.

61. Umarov, M. M., Skrypnikov, A. V., Chernyshova, E. V. \& Mikova, E. Yu. (2018). The use of digital terrain models for tracing forest roads. Lesnoy zhurnal, no 2. 58-69.

62. Chernikov, E. A., Zobov, S. Yu. (2014). Technological principles for the manufacture of blocks of the track covering of temporary logging roads from wood fiber composite materials (WFCM). Voronezhskiy nauchno-tekhnicheskiy Vestnik, no 4 (10). 88-91.

63. Chernyshova, E. V., Skrypnikov, A. V., Samtsov, V. V. \& Abasov, M. A (2019). Logging highways in the transport network of a timber enterprise. Lesnoy zhurnal, no 2.95-101.

64. Shegelman, I. R. (2013). Formation of end-to-end technologies of forest industry: scientific and practical aspects. Global'nyy nauchnyy potentsial, no 8 (29). 119-122.

65. Shegelman, I. R., Skrypnik, V. I. \& Kuznetsov, A. V. (04/20/2013). Patent of the Russian Federation №2479200 "Method of creating a whisker coating in areas with low bearing capacity of soils."

66. Shegelman, I. R., Schukin, P. O. \& Petukhov, R. A. (2011). Resource approach to the development of a regional network of forest roads. Perspektivy nauki, no 11(26). 88-191.

67. Shegelman, I. R., Vasiliev, A. S., Schukin, P. O., Aminov, V. N. \& Kameneva, E. E. (12.10.2017). Patent of the Russian Federation № 2633396 "Method of crushing lumpy rock in a jaw crusher."

68. Shegelman, I. R., Vasiliev, A. S., Shchukin, P. O., Aminov, V. N. \& Kameneva, E. E. (July 01, 2015). Patent of the Russian Federation № 158121 "Jaw crusher".

69. Shirnin, Yu. A., Shirnin, A. Yu., Lebedeva, N. Yu. \& Fedorova, I. Ya. (08.20.2013). Patent of the Russian Federation №2489844 "Method for the development of forest areas routes of oil and gas pipelines and transmission lines."

7. Saibara, K., Nishigaki, S., Matsuda, F. \& Kubota, S. (2014). Contrivances to assist forest machine operator on forest road with steep slope Proceedings of the 31st International Symposium on Automation and Robotics in Construction and Mining (ISARC). 458-465.

70. Stefan, Yu. V., Bondarev, B. A. \& Yankovsky, L. V. (2016). The use of cubic molten slag rubble for the construction and repair of main fores roads. Remont. Vosstanovleniye. Modernizatsiya, no 10. 11-16.

71. Ganjali, M., \& Teimourpour, B. (2016). Identify Valuable Customers of Taavon Insurance in Field of Life Insurance with Data Mining Approach UCT Journal of Research in Science, Engineering and Technology, 4(1), 1-10.

72. Ngirwa, C. C., \& Ally, M. (2018). An ICT Based Solution for Pesticides Authenticity Verification: A Case of Tanzania. Journal of Information Systems Engineering \& Management, 3(4), 27.

73. Singh, P., Teoh, S. H., Cheong, T. H., Md Rasid, N. S., Kor, L. K., \& Md Nasir, N. A. (2018). The Use of Problem-Solving Heuristics Approach in Enhancing STEM Students Development of Mathematical Thinking. International Electronic Journal of Mathematics Education, 13(3), 289-303. https://doi.org/10.12973/iejme/3921

8. Sessions, J. A. (1987). Heuristic algorithm for the solution of the variable and fixed cost transportation problem. Symposium on System Analysis in Forest Resources. Univ. of Georgia, Athens. 324-336.

9. Shegelman, I. R., Vasiliev, A. S. \& Shchukin, P. O. (2018a). Particularities of Ensuring Food Security in the Conditions of the North of Russia. Astra Salvensis, no 6. 941-949.

\section{AUTHORS PROFILE}

Shegelman Ilia Romanovich, Doctor of Technical Sciences, Professor, Cross-cutting technology and economic security, Petrozavodsk State University (PSU), 33, Lenina pr., 185910, Petrozavodsk, Republic of Karelia, Russia;

Vasilev Aleksey Sergeevich, Candidate of Technical Sciences, Associate Professor, Technologies and organizations of the forest complex, Petrozavodsk State University (PSU), 33, Lenina pr., 185910, Petrozavodsk, Republic of Karelia, Russia;

Galaktionov Oleg Nikolaevich, Doctor of Technical Sciences, Associate Professor, Technologies and organizations of the forest complex, Petrozavodsk State University (PSU), 33, Lenina pr., 185910, Petrozavodsk, Republic of Karelia, Russia;

Kuznetsov Alexey Vladimirovich, Doctor of Technical Sciences, Associate Professor, Technologies and organizations of the forest complex, Petrozavodsk State University (PSU), 33, Lenina pr., 185910, Petrozavodsk, Republic of Karelia, Russia;
Sukhanov Yury Vladimirovich, Candidate of Technical Sciences, Associate Professor, Technologies and organizations of the forest complex, Petrozavodsk State University (PSU), 33, Lenina pr., 185910, Petrozavodsk, Republic of Karelia, Russia. 